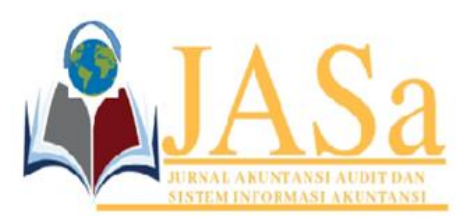

JASa (Jurnal Akuntansi, Audit dan Sistem Informasi Akuntansi)

Vol. 5 No.1/ April 2021

ISSN 2550-0732 print / ISSN 2655-8319 online

DOI;10.36555/jasa.v5i1.1470

\title{
MEASUREMENT OF FINANCIAL PERFORMANCE USING THE CONCEPT OF VALUE FOR MONEY IN THE GOVERNMENT OF BANDUNG CITY
}

\author{
Ratumas Resa Anggia Sakti \\ Universitas Padjadjaran, Indonesia \\ rts19001@mail.unpad.ac.id
}

\begin{abstract}
In the context of transparency and accountability of public money management, the Bandung City Government uses a tool called e-budgeting. Not only has the objectives of transparency and accountability, but the use of a budget formulation application system using e-budgeting is expected to be able to improve the government's financial performance to be more economical, efficient, and effective. This study aims to measure the financial performance of the Bandung City Government before and after the use of e-budgeting using the concept of value for money for the 2014-2019 fiscal year. Data analysis used descriptive analysis with quantitative research methods. The results of the study are based on the Analysis of the Bandung City Government Budget Realization Report for the 2014-2016 fiscal year (before the use of e-budgeting) using the concept of Value for money, Bandung City Government financial performance shows economic criteria $(78.72 \%)$, inefficient $(98.04 \%)$ and effective $(90.65 \%)$. Meanwhile for the 2017-2019 fiscal year (after the use of e-budgeting) the financial performance of the Bandung City Government shows economic criteria (83.39\%), inefficient (99.48\%), and quite effective (88\%).
\end{abstract}

Keywords: Performance Measurement, Budgeting, Value for Money, E-Budgeting

\section{INTRODUCTION}

The success in the implementation of services to the community is greatly influenced by government performance. The government must be able to provide the best service to the community as a public sector organization that his duties and functions in carrying out the government bureaucracy so that its role cannot be replaced by the private sector. At present, both the central and local governments are faced with a lot of demands both from an internal and external perspective of the government. The services provided by the government must be good and maximal because every society wants to receive quality public services and has a standard that can be used as a measure of successful performance. (Agustin \& Subardjo, 2017).

Based on Law Number 17 of 2003 concerning State Finance(Government of Indonesia, 2003), both the Central and Local Governments are required to implement performance-based budgets in each of their budget implementations. Performancebased budgeting is a system in budgeting based on work performed on the goals, vision, mission, and strategic plans of an organization. To date, dln the implementation of the budget, there are still several problems, including wasteful use of the expenditure budget and budget realization that is not on target, which ultimately affects the performance of the Government. Weak budget planning allows budget ineffectiveness and efficiency and 


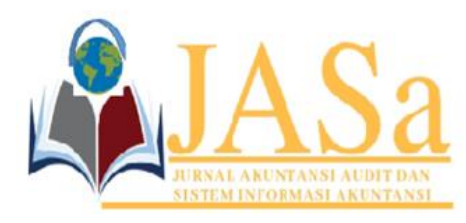

JASa (Jurnal Akuntansi, Audit dan Sistem Informasi Akuntansi)

Vol. 5 No.1/ April 2021

ISSN 2550-0732 print / ISSN 2655-8319 online

DOI; $10.36555 /$ jasa.v5i1.1470

opens up space for corruption. In the article(Suwiknyo, 2018) stated that Indonesia Corruption Watch considers the public service sector to be very vulnerable to cases of budget corruption, especially in the process of procuring goods and services. The financial accountability aspect of the Government must demonstrate openness to management and the ability to spend public money economically, efficiently, and effectively.

A budget is a controlling tool for carrying out activities in achieving the vision, mission, and strategic plan of an organization so that their implementation is more effective and efficient. The government is given the authority to manage public money which is managed in the regional revenue and expenditure budget (APBD). Accountability and transparency in the management of APBD funds through government financial reports is a form of accountability to the people. Accountable and transparent regional financial governance is an indicator of the achievement of good corporate governance (GCG). Assessment of organizational accountability in better and more targeted public services can be seen by measuring the financial performance of local governments.

The implementation of performance-based budgeting is closely related to the vision, mission, and strategic plan of an organization, which in its implementation must be oriented towards the output that the organization has set. In government administration, there are four stages of the budget cycle according to (Mahsun, 2013) consisting of (1) the Budget preparation stage, at this stage an estimate of the expenditure budget is carried out based on the estimated available income. Expenditure estimates are of course based on the vision, mission, and goals of the organization. At the budget preparation stage, before approving the expenditure plan, it is necessary to pay attention to the income plan. (2) Budget Ratification Stage, in this stage, the executive leadership provides rational arguments for all questions from the legislature regarding budget planning. The utmost integrity of the executive is required at this stage. This stage is known as the budget approval stage. (3) The Budget Implementation Stage. In this stage, Public financial managers need an accounting information system and a management control system that is reliable and adequate for the agreed budget planning and control, which also helps to control budget execution and can even be relied upon for the budget preparation stage of the next period. (4) Reporting and Evaluation Stage is a stage related to the accountability aspect which is a form of accountability for the implementation of budget activities which is made in the form of a work report.

In its implementation, a performance approach budget focuses on the concept of value for money and monitoring of performance outputs. Budget performance is an alternative to achieve good governance which focuses on performance results. Traditional methods of budgeting have weaknesses, including that they can cause continuous errors and not achieving output or performance because budgeting is not carried out with a more in-depth study (Sujarweni, 2015). A budget that is not performance-oriented and ineffective can derail plans that have already been drawn up. In research(Kurrohman, 2013) performance appraisal based on the concept of value for money shows that local governments are more economical and efficient in their financial management after using performance-based budgets. For this reason, sustainable

Submitted: October 30, 2020; Accepted: March 01, 2021; Revised: March 23, 2021; Published: April 24, 2021; Website: http://journalfeb.unla.ac.id/index.php/jasa 


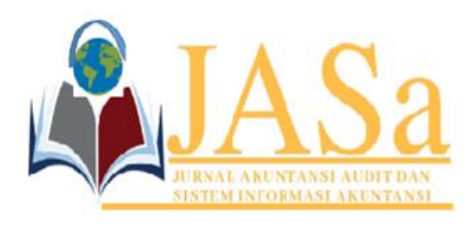

JASa (Jurnal Akuntansi, Audit dan Sistem Informasi Akuntansi)

Vol. 5 No.1/ April 2021

ISSN 2550-0732 print / ISSN 2655-8319 online

DOI; $10.36555 /$ jasa.v5i1.1470

performance measurement is needed as an effort to improve the achievement of the success of public services in the future. An assessment of the accountability for the financial performance of a government organization can use an analysis of the target achievement and realization of the revenue and expenditure budget of the Regional Revenue and Expenditure Budget (APBD). The resulting output is not sufficient to assess the performance of the Government, but must jointly consider the integrated inputs, outputs, and outcomes.

In government organizations, Value for money is the core of financial performance measurement which has three concepts in developing performance indicators that can measure economic levels, efficiency, and effectiveness. (Mahmudi, 2013). In line with what was conveyed by(Mahmudi, 2013), (Halim, 2012)states that the concept of value for money is a concept for measuring the economy, effectiveness, and efficiency of the performance of programs, activities, and organizations. Value for money also implies an appreciation of the value of money.

The implementation of the value for money concept in government organizations has benefits, namely: (1) Increasing effectiveness in targeted public services. (2) Improve the quality and quality of public services. (3) By achieving the criteria of efficiency, it can reduce costs in implementing public services so that savings can be achieved in the use of inputs. (4) Expenditure allocation is oriented towards the public interest. (5) Increase awareness of public money (public costs awareness) as the root of implementing public accountability(Mardiasmo, 2011).

There are several studies related to measuring financial performance in the public sector, including(Agustin \& Subardjo, 2017) researched to determine the concept of value for money which can be measured from the 2015 Government Agency Performance Accountability Report (LAKIP) at the Surabaya City Revenue and Financial Management Office, the results of this study are that the performance of the Surabaya City Revenue and Financial Management Service can be assessed as economical, efficient, and effective. According to(Octariani et al., 2017)Performance-based budgets and the quality of human resources influences the quality of SKPD budgets. Research on performance measurement of the City of Tomohon by(Sumual et al., 2017) found that during 2013-2016, Tomohon City received the title of an effective City, but the independence and efficiency of Tomohon City have not been achieved so that it can be said that its financial performance is not good.

To support the creation of Good Governance, a quality budget that is based on financial performance, economical, efficient, effective, transparent, and accountability is needed. The Ministry of Home Affairs of the Republic of Indonesia (Kemendagri RI) encourages all Regional Governments in financial management, starting from planning and budgeting to use an electronic budgeting system or what is called $\mathrm{E}$ Budgeting as an effort to create a transparent and accountable government financial management(Carlos KY Paath, Yustinus Paat, Teguh L Rahmadi, 2017). The electronic-based budgeting system (E-Budgeting) aims to simplify the budget planning process to use the budget effectively and efficiently. One of the local governments that have implemented budgeting using e-budgeting applications is the Surabaya City Government. According to(Gunawan, 2016)With e-budgeting, the implementation of 


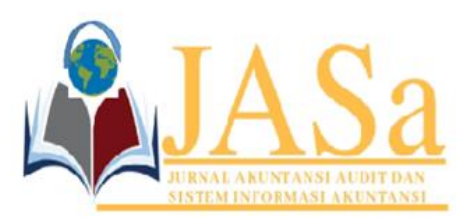

JASa (Jurnal Akuntansi, Audit dan Sistem Informasi Akuntansi)

Vol. 5 No.1/ April 2021

ISSN 2550-0732 print / ISSN 2655-8319 online

DOI; $10.36555 /$ jasa.v5i1.1470

budget accountability and transparency in the City Government of Surabaya has been realized as evidenced by the publication of the implementation of the budgeting process and activity program as a whole.

Bandung City Government is one of the cities that also implement budgeting using e-budgeting. In the article(Budget Efficiency, City Government of Bandung Prepare EBudgeting, 2016)The Mayor of Bandung said that by using e-budgeting, the Bandung City Government could better manage the budget that was issued to make it more efficient and the program of activities in each of the Regional Work Units would be more effective.

Based on the phenomena, theories, and previous research described above, it can be concluded that performance-based budgeting has been carried out by the Regional Government but the results of the performance-based budgeting are still not maximal and must have supported both in terms of human resources, technology and quality of the budget. For this reason, this research will measure the financial performance of the Bandung City government which has implemented performance-based budgeting and has been supported by technology as a control to achieve an economical, efficient and effective budget in the form of an e-budgeting budgeting application.

The purpose of this study is to measure financial performance using the concept of value for money (economical, efficient, and effective) in the Bandung City Government in 2014-2016 (before the use of e-budgeting) and 2017-2019 (after the use of ebudgeting). The results of this study are expected to be able to become material for evaluation and consideration for decision making in determining program activities and measuring the financial performance of the Bandung city government in the future so that budget management can be carried out economically, efficiently, and effectively as a condition for the creation of good corporate governance (GCG).

\section{METHODS}

Data analysis used descriptive analysis with quantitative research methods. According to(Uma Sekaran, 2013)Descriptive research is a type of conclusive research that has the main purpose of describing something, usually an explanation of market characteristics or functions. The data source used is primary data obtained directly from the Financial and Asset Management Agency (BPKA) of the Bandung City Government. This study analyzes the data from the Bandung City Government Budget Realization Report (LRA) from 2014-2019. The data information consists of the LRA of the Bandung City Government in 2014 - 2016 where the Bandung City Government in preparing its budget is performance-based but has not used the e-budgeting application, and for the 2017-2019 Budget Realization Report (LRA) data it is used to measure financial performance after use of e-budgeting applications. To analyze this data, using the calculation of the ratio of measurement of financial performance value for money with economic indicators, efficient and effective. After getting the results of the data analysis, the writer will explain descriptively and make conclusions on the results of the analysis of the performance measurement of the Bandung City Government using the concept of value for money. Economical calculations using the formulas and criteria in the table. 1 as follows:

Submitted: October 30, 2020; Accepted: March 01, 2021; Revised: March 23, 2021; Published: April 24, 2021; Website: http://journalfeb.unla.ac.id/index.php/jasa 


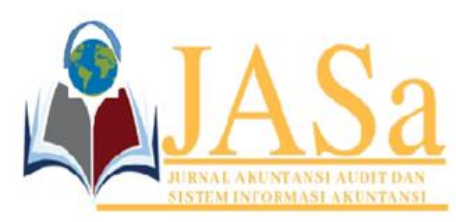

JASa (Jurnal Akuntansi, Audit dan Sistem Informasi Akuntansi)

Vol. 5 No.1/ April 2021

ISSN 2550-0732 print / ISSN 2655-8319 online

DOI;10.36555/jasa.v5i1.1470

$$
\text { ECONOMICAL }=\frac{\text { Expenditure Budget Realization }}{\text { Expenditure Budget Target }} \times 100 \%
$$

Table. 1

Economic Criteria

\begin{tabular}{lcl}
\hline & Size & \multicolumn{1}{c}{ Criteria } \\
\hline 1) & Ratio $<100 \%$ & Economical \\
2) & Ratio $=100 \%$ & Economically \\
& & balanced \\
3) Ratio $>100 \%$ & Not economical \\
\hline \multicolumn{3}{c}{ Source: Mahsun (2006) }
\end{tabular}

Efficient calculation using the formulas and criteria in table 2 below:

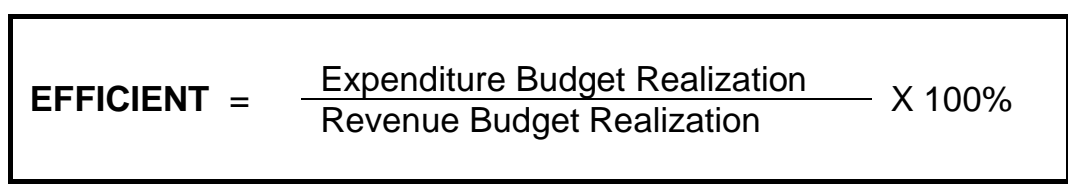

Table 2

Efficient Criteria

\begin{tabular}{|c|c|c|}
\hline & Size & Criteria \\
\hline 1) & ratio $\leq 10 \%$ & Very Efficient \\
\hline 2) & $\begin{array}{ll}\text { ratio } & 10.01 \% \\
20 \% & \end{array}$ & Efficient \\
\hline 3) & $\begin{array}{l}\text { ratio } 20.01 \% \\
30.00 \%\end{array}$ & Simply Efficient \\
\hline 4) & $\begin{array}{l}\text { ratio } 30.01 \% \\
40.00 \%\end{array}$ & Less efficient \\
\hline 5) & ratio $\geq 40.01 \%$ & Not efficient \\
\hline
\end{tabular}

Effective calculations use the following formulas and criteria in table 3 :

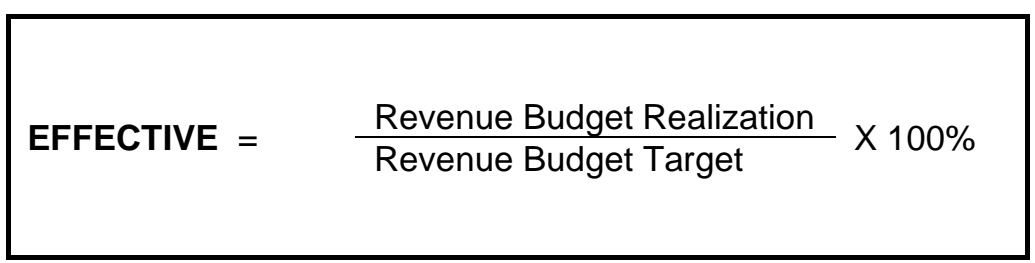

Submitted: October 30, 2020; Accepted: March 01, 2021; Revised: March 23 2021; Published: April 24, 2021; Website: http://journalfeb.unla.ac.id/index.php/jasa 


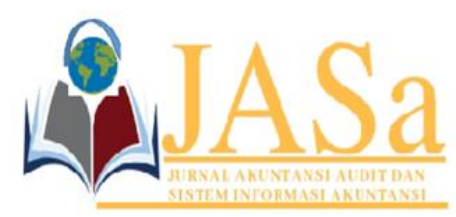

JASa (Jurnal Akuntansi, Audit dan Sistem Informasi Akuntansi)

Vol. 5 No.1/ April 2021

ISSN 2550-0732 print / ISSN 2655-8319 online

DOI;10.36555/jasa.v5i1.1470

Table 3

Effective Criteria

\begin{tabular}{|c|c|c|}
\hline & Size & Criteria \\
\hline & ratio $\geq 100 \%$ & Very effective \\
\hline 2) & $\begin{array}{l}\text { ratio } 90.01 \% \\
100 \%\end{array}$ & Effective \\
\hline 3) & $\begin{array}{l}\text { ratio } 80.01 \% \\
90.00 \%\end{array}$ & Effective enough \\
\hline 4) & $\begin{array}{l}\text { ratio } 60.01 \% \\
80.00 \%\end{array}$ & Less effective \\
\hline 5) & ratio $\leq 60.00 \%$ & Ineffective \\
\hline
\end{tabular}

Source: Mahmudi (2005)

\section{RESULTS AND DISCUSSION}

Performance Measurement uses the concept of Value for Money (VFM) on the 2014-2016 Budget Realization Report (LRA) (preparation of budgets before the use of e-budgeting) and 2017 - 2019 (e-budgeting) in the City Government of Bandung with target data and the realization of Regional Revenue and Expenditure in table 4 below:

Table. 4

Target and Realization of Bandung City Government Revenue and Expenditure Budget The fiscal Year 2014 - 2019

\begin{tabular}{|c|c|c|c|c|}
\hline \multirow[t]{2}{*}{ YEAR } & \multicolumn{2}{|c|}{ INCOME } & \multicolumn{2}{|c|}{ EXPENDITURE } \\
\hline & $\begin{array}{l}\text { TARGET } \\
\text { (Rp) }\end{array}$ & $\begin{array}{l}\text { REALIZATION } \\
\text { (Rp) }\end{array}$ & $\begin{array}{l}\text { TARGET } \\
\text { (Rp) }\end{array}$ & $\begin{array}{l}\text { REALIZATION } \\
\text { (Rp) }\end{array}$ \\
\hline 2014 & $5,302,471,398,707.15$ & $4,953,940,629,444.00$ & $5,717,545,328,505.00$ & $4,435,589,826,032.00$ \\
\hline 2015 & $5,455,361,616,094.00$ & $5,098,071,916,848.00$ & $6,553,368,797,049.00$ & $5,201,938,207,165.00$ \\
\hline 2016 & $6,684,129,617,384.00$ & $5,685,213,859,929.00$ & $7,360,848,469,022.00$ & $5,830,413,719,644.00$ \\
\hline 2017 & $6,345,545,693,082.00$ & $5,735,006,649,088.00$ & $6,752,914,685,771.00$ & $5,541,718,107,062.75$ \\
\hline 2018 & $6,851,137,385,730.00$ & $5,939,997,423,418.00$ & $7,418,332,448,642.00$ & $6,114,449,093,123.40$ \\
\hline 2019 & $7,341,971,914,999.16$ & $6,381,818,944,636.00$ & $7,363,910,780,008.01$ & $6,310,647,268,360.67$ \\
\hline
\end{tabular}

Based on data from the Budget Realization Report (LRA) in table 4 above, it can be seen that from 2014 to 2019 the realization of the revenue budget has always failed to reach the target. Realized revenue, which consists of Original Regional Revenue (PAD), Transfer Revenue, etc. Legitimate income is lower in value than the actual expenditure consisting of operational expenditure, capital expenditure, and unexpected expenditure. However, the realization of revenue has continued to increase starting in 2014, the realization of revenue of Rp. 4,953,940,629,444.00. In 2015, there was an increase of $2.9 \%$ from the realization of revenue in 2014 to $\mathrm{Rp}$. 5,098,071,916,848.00, in 2016 it increased again by $\mathrm{Rp}$. $5,685,213,859,929.00$, in 2017 and increase of Rp. 5,735,006,649,088.00. In 2018 the realization of Return's income increased by Rp. 5. 939,997,425,418.00, in 2019 it increased again by $6.92 \%$ to Rp. $6,381,818,944,636.00$.

The expenditure realization in 2014 was Rp. 4,435,589,826,032.00 in 2015 and 2016 expenditure realization increased respectively by $\mathrm{Rp}$. 5,201,938,207,165.00 and $\mathrm{Rp}$. $5,830,413,719,644.00$. In 2017, the expenditure realization decreased to $R p$. 


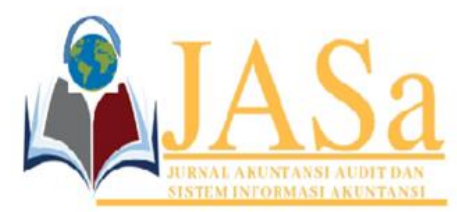

\author{
JASa (Jurnal Akuntansi, Audit dan Sistem Informasi Akuntansi) \\ Vol. 5 No.1/ April 2021 \\ ISSN 2550-0732 print / ISSN 2655-8319 online \\ DOI; $10.36555 /$ jasa.v5i1.1470
}

$5,541,718,107,061.75$ this is probably because budget preparation began using the ebudgeting application and expenditure realization increased again in 2018 by $\mathrm{Rp}$. $6,114,449,093,123.40$ in 2019 amounting to Rp. 6,310,647,268,360.67. The target data and the realization of the budget and expenditures are processed using the value for money ratio formula with the results of measuring the financial performance ratios in table 5 below:

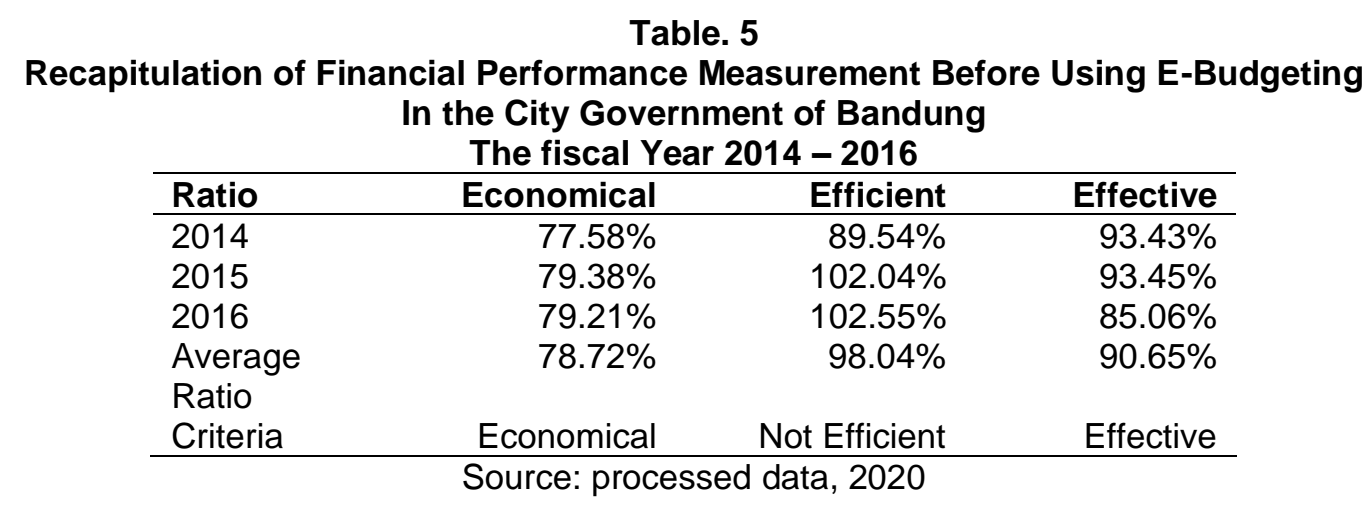

From the results of the calculation of the data above, it can be seen that the financial performance of the Bandung City Government before using e-budgeting with processed data starting from 2014-2016 using the Value For Money Ratio produces economic, inefficient but effective criteria. Economic criteria are given following the results of the analysis in 2014 the percentage of the economic ratio is $77.58 \%$, in 2015 the percentage is $79.38 \%$, and in 2016 the percentage is $79.21 \%$ with an average ratio of $78.72 \%$. These results can be interpreted that the Bandung City Government in preparing the budget before the use of e-budgeting has gone well because its financial performance shows economic criteria. Bandung City Government can minimize unproductive spending. This is in line with what was conveyed by(Mardiasmo, 2011) whereas in budget management to achieve economic criteria, public sector organizations can minimize input resources by avoiding wasteful spending.

According to (Mardiasmo, 2011) performance standards or targets that have been set using a comparison between output or input represent efficiency. The results of measuring financial performance with the concept of Value for money at efficient ratios, Bandung City Government on its financial performance fall into the inefficient criteria. These results can be seen from the processed data in 2014 which showed a percentage yield of $89.54 \%$, in 2015 amounting to $102.04 \%$, and in 2016 amounting to $102.55 \%$ with an average efficiency ratio of $98.04 \%$. shows that although the Bandung City Government can minimize expenditure, the actual value of expenditure is greater than the expected income. Analyzing the budget realization report (LRA) of the Bandung city government in 2014, the actual revenue value is greater than the actual expenditure. whereas in 2015 and 2016 expenditure realization was greater than revenue realization. This matter may occur because the Government of Bandung City wants to improve the overall quality of service. Therefore, it requires the target and realization of the APBD

Submitted: October 30, 2020; Accepted: March 01, 2021; Revised: March 23, 2021; Published: April 24, 2021; Website: http://journalfeb.unla.ac.id/index.php/jasa 


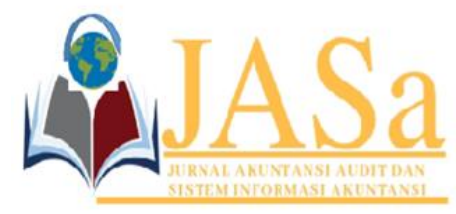

JASa (Jurnal Akuntansi, Audit dan Sistem Informasi Akuntansi)

Vol. 5 No.1/ April 2021

ISSN 2550-0732 print / ISSN 2655-8319 online

DOI; $10.36555 /$ jasa.v5i1.1470

budget to support more public and regional apparatus needs in improving the quality of performance of the Bandung City Government.

The effective ratio of the processed data on the realization of the Bandung City Government budget before using e-budgeting for three years from 2014 - 2016 can be said to be effective because the average ratio is $90.65 \%$. It can be seen in table 6 that the effective ratio in 2014 was $93.43 \%$, in 2015 it was $93.45 \%$ and in 2016 it fell to $85.06 \%$. From these results, it can be illustrated that the financial performance of the Bandung City government during 2014-2016 has been effective. The achievement of goals and objectives of activity programs in providing services in the City Government of Bandung. The results of measuring financial performance after using e-budgeting can be seen in Table 6 below:

Table. 6

Recapitulation of Financial Performance Measurement After Using E-Budgeting In the City Government of Bandung The fiscal Year 2017- 2019

\begin{tabular}{lrrr}
\hline Ratio & Economical & Efficient & Effective \\
\hline 2017 & $82.06 \%$ & $96.63 \%$ & $90.38 \%$ \\
2018 & $82.42 \%$ & $102.94 \%$ & $86.70 \%$ \\
2019 & $85.70 \%$ & $98.88 \%$ & $86.92 \%$ \\
Average & $83.39 \%$ & $99.48 \%$ & $88 \%$ \\
Ratio & & Not Efficient & Effective Enough \\
Criteria & Economical &
\end{tabular}

The financial performance of the Bandung City Government in 2017 - 2019 based on the processed data in table 6 above shows that after the use of e-budgeting, financial performance shows economic, inefficient, and quite effective criteria. The economic ratio in 2017 showed a result of $82.07 \%$, in 2018 the economic ratio was $82.42 \%$, and in 2019 it decreased to $83.39 \%$ so that an average economic ratio was obtained of $83.39 \%$. Judging from the results of the calculation of economic ratios after the use of e-budgeting from 2017 - 2019 has increased compared to before the use of e-budgeting, which means that the Bandung City Government is increasingly economical in managing the revenue and expenditure budget. From this data, it can be seen that the Bandung City Government has shown better performance in financial performance by minimizing unproductive expenditure which can lead to waste. This is inseparable from good budget planning, supported by good budgeting resources and applications so that an appropriate cost allocation can be achieved with a certain level of quality and the best price. Success has no meaning if the costs incurred for the realization of the expenditure budget are greater than the set budget target. supported by resources and good budgeting applications so that the right cost allocation can be achieved at a certain level of quality and the best price. Success has no meaning if the costs incurred for the realization of the expenditure budget are greater than the set budget target. supported by good resources and budgeting applications so that the right cost allocation can be achieved at a certain quality level and the best price. Success has no meaning if the 


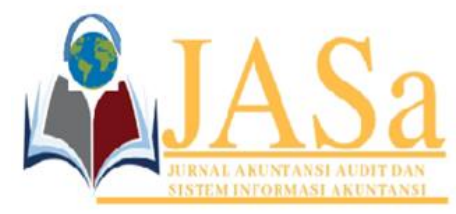

JASa (Jurnal Akuntansi, Audit dan Sistem Informasi Akuntansi)

Vol. 5 No.1/ April 2021

ISSN 2550-0732 print / ISSN 2655-8319 online

DOI; $10.36555 /$ jasa.v5i1.1470

costs incurred for the realization of the expenditure budget are greater than the set budget target.

According to (Mardiasmo, 2011) Efficiency is the ratio between the output/input associated with predetermined performance standards or targets. The results of processed data on efficient ratios during 2017 - 2019 show that the Bandung City Government is inefficient in financial performance. The efficiency ratio in 2017 showed a result of $96.63 \%$, in 2018 the efficient ratio became $102.94 \%$ while in 2019 it had an efficient ratio of $98.88 \%$ so that the average efficiency ratio was $99.48 \%$. This is due to a large amount of expenditure realization compared to revenue realization so that the financial performance of the Bandung City Government before and after the use of ebudgeting is in the inefficient criteria. These results are in line with research conducted by (Wu \& Guo, 2015) where the research was carried out in China which resulted in the use of e-government not all provinces in China succeeded in making efficiency.

The average effective ratio in 2017 - 2019 was $88 \%$, indicating that the financial performance of the Bandung City Government for the three years was quite effective, with the effective ratio in 2017 of $90.38 \%$, in 2018 it fell to $86.70 \%$, and in 2019 amounted to $86.92 \%$. This indicates that the revenue target was not achieved or the value of the revenue realization was below the revenue target. Analyzing from the Bandung City Government's budget realization report for 2017-2019, transfer revenue provides the largest contribution to revenue realization than regional original revenue and other legal income.

Budgeting is a technical task, so the use of the system or application as a tool in budgeting must be followed by the quality of resources (human and financial) for the accuracy of determining revenue and expenditure targets, implementing program activities on time according to the scheduled plan, and evaluation of inputs, outputs regularly to achieve outcomes and improve financial performance. Control over expenditures for goods and services must always be exercised because the money that is managed is public money. Every change in the system must be followed by maximum resources, transparency, and accountability for the achievement of good corporate governance.

\section{CONCLUSION}

This study aims to measure the financial performance of the Bandung City Government before and after the use of e-budgeting using the concept of value for money. Based on the results of the analysis and discussion that has been carried out using the Bandung City Government's budget realization report (LRA) data for the 20142019 fiscal year, it can be concluded that the results of measuring financial performance use the concept of Value for money before the use of e-budgeting in 2014-2016, Bandung City Government included in Economic criteria, inefficient, but effective, while the results of measuring the financial performance of the Bandung City government after using e-budgeting based on the concept of measuring value for money in the 2017-2019 fiscal year are categorized into economic, inefficient and quite effective criteria.

Submitted: October 30, 2020; Accepted: March 01, 2021; Revised: March 23, 2021; Published: April 24, 2021; Website: http://journalfeb.unla.ac.id/index.php/jasa 


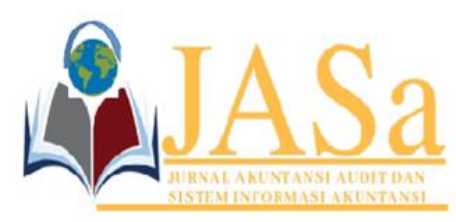

JASa (Jurnal Akuntansi, Audit dan Sistem Informasi Akuntansi)

Vol. 5 No.1/ April 2021

ISSN 2550-0732 print / ISSN 2655-8319 online

DOI; $10.36555 /$ jasa.v5i1.1470

\section{REFERENCES}

Agustin, DR, \& Subardjo, A. (2017). The concept of value for money in measuring the performance of public sector services. Journal of Accounting Science and Research, 6 (6), 1-15.

Carlos KY Paath, Yustinus Paat, Teguh L Rahmadi, AS / A. (2017). Ministry of Home Affairs Encourages the Implementation of E-Budgeting. Www.Beritasatu.Com. https://www.beritasatu.com/aditya-I-djono/nasional/427605/kemdagri-dorongpenerapan-ebudgeting

Budget Efficiency, City Government of Bandung Prepare E-Budgeting. (2016). Www.Republika. Co.ld. https://republika.co.id/berita/koran/newsupdate/16/05/24/o7nxs65-effficiency-anggaran-pemkot-bandung-siapanebudgeting

Gunawan, DR (2016). Application of the E-Budgeting System to Transparency and Accountability of Public Finance (Study at the Surabaya City Government). Journal of Accounting, 8 (1), 72-102.

Halim, A. and SK (2012). Public sector accounting. Four Salemba.

Kurrohman, T. (2013). Evaluation of performance-based budgeting through based financial performance. Journal of Accounting Dynamics, 5 (1), 1-11.

Mahmudi. (2013). Public Sector Management (second). UPP STIM YKPN.

Mahsun, M. (2013). Public Sector Performance Measurement. BPFE.

Mardiasmo. (2011). Public sector accounting. Publisher Andi.

Octariani, D., Akram, A., \& Animah, A. (2017). BUDGET BASED ON PERFORMANCE, HUMAN RESOURCES, AND QUALITY OF SKPD BUDGET (A Structural Test). Indonesian Accounting and Financial Research, 2 (1), 27-41. https://doi.org/10.23917/reaksi.v2i1.3621

Indonesian government. (2003). Law Number 17 of 2003 concerning State Finances (Issue 1, pp. 1-40). State Secretariat.

Sujarweni, VW (2015). Public sector accounting. Press Library.

Sumual, CD, Kalangi, L., \& Ger Sungai, NYT (2017). Analysis of Financial Performance Measurement in Tomohon City Government. Going Concern: Journal of Accounting Research, 12 (2), 782-791. https://doi.org/10.32400/gc.12.2.18133.2017

Suwiknyo, E. (2018). Corruption Cases: These Are Budget Posts That Often Become Bancakan. Www.Bisnis.Com. https://ekonomi.bisnis.com/read/20180227/9/743539/kasus-korupsi-ini-dia-pospos-anggaran-yang-sering-jadi-bancakan

Uma Sekaran, RB (2013). Research Methods for Business. Four Salemba.

Wu, J., \& Guo, D. (2015). Measuring E-government performance of the provincial government website in China with slacks-based efficiency measurement. Technological Forecasting and Social Change, 96, 25-31. https://doi.org/10.1016/j.techfore.2015.01.007 